\title{
Art and Teaching: \\ Understanding Through Narratives of Experience \\ Patrick Fahey
}

\begin{abstract}
In Lawrence Weschler's (1982) book, Seeing Is Forgetting the Name of the Thing One Sees, the artist Robert Irwin shared his beliefs and ideas about teaching. Irwin related to Weschler that he would attempt to recapitulate in his students the process through which he himself had progressed. Insistent that they first experience the historical roots of their activities, the central focus and real questions Irwin was trying to engender in his students were actually located less in the past than in themselves. He explained:
\end{abstract}

All the time my ideal of teaching has been to argue with people on behalf of the idea that they are responsible for their own activities, that they are really, in a sense, the question, that ultimately they are what it is they have to contribute. The most critical part of that is for them to begin developing the ability to assign their own tasks and make their own criticism in direct relation to their own needs and not in light of some abstract criteria. Because once you leam how to make your own assignments instead of relying on someone else, then you have learned the only thing you really need to get out of school, that is, you've learned how to learn. You've become your own teacher. After that you can stay on-for the facilities, the context, the dialogue, the colleagueship, the structure, and so forth-but you'll already be on your own (p. 120).

Irwin also reminded that once students had been brought to this threshold, the teacher was faced with another challenge: letting the student emerge-find his or her own way without interruptions and unnecessary involvement. Irwin admitted that he may not like what his students were doing but "my feelings at that stage were beside the poirt; or rather, since my relationship to those students had shifted from that of leader to co-participant, my personal likes, dislikes, and biases were no longer critical to their development except as just one more issue up for discussion" (p. 120).

The relationship between student and teacher is precious, sometimes tenuous, always changing and has been written about by many artists, educators and philosophers. Martin Buber (1970) described the unfolding of such a relationship as "mutuality". In this relationship the teacher must encounter the student as a partner in a bipolar situation. To give influence, unity, and meaning, the teacher must live through this situation in all 
aspects-not only from his or her point of view but also from that of the student (p. 178). Buber (1970) wrote:

$\mathrm{He}$ (the teacher) must practice the kind of realization that I call embracing (umfassung). It is essential that he should awaken the I-You relationship in the pupil, too, who should intend and affirm his educator as this particular person; and yet the educational relationship could not endure if the pupil also practiced the art of embracing by living through the shared situation from the educator's point of view (p. 178).

The reciprocity involved in this situation is an important part of the relationship. It allows for the examination of the past, present and future to achieve what Buber (1965) referred to as a fully-realized and responsible person who might provide for an experience, occasion or impetus for another's becoming.

The importance of student and teacher indentifying through meaningful relationships is clearly understood by Buber and affirmed by many including Grumet (1975) who suggested that whenever we speak of education, we are speaking of an individual's experience in the world: a dialogue with the world of their experience. According to Grumet, one cannot talk about education without talking about a dialectic between a person and his or her world. Schutz (1970) acknowledged that communication can occur only within the reality of the outer world ...'(p. 203). Again, the importance and quality of communication is an essential aspect in the relationship between teacher and student and is revealed in the following passage provided by Schutz (1970):

It appears that all possible communication presupposes a mutual tuning-in relationship between the communicator and the addressee of the communication. This relationship is established by the reciprocal sharing of the other's flux of experiences in inner time, by living through a vivid present together, by experiencing this togetherness as a "We" (p. 226).

Kenneth Belttel (1973) recognized the import of such ideas as necessary in understanding our teaching and our making of art. His own research maintained that "reflexivity in inquiry calls for an acknowledgement of the fallibility, humanity, and especially the on-going history of learning of the inquirers. At bottom is ... but a kind of awe and reverence for the phenomena themselves and an acknowledgement, as Collingwood puts it, that '. . . in the last resort nothing but the knower can be known' " (p. 124).

The ideas contained in these passages are beautifully and clearly exampled in Beittel's 1963 article "David's Stoneware." Here Beittel shared the story of his relationship with and observations of a young boy named David as 
he worked, cleaned, and created art in an artist's ceramics studio. Beittel's account gave concrete meaning to Buber's idea of "mutuality" and Schutz's "We-relationship". Given the freedom to fully participate in this community, David became an authentic and respected member. Rights and freedom of choice were available to David, as was the responsibility that accompanied such privileges. He got to use the best tools and materials in the studio, but he also had to mix and wedge the clay, clean his brushes, point them, clean the shop and help with any problems. Although young, David was treated like any other member of this "stoneware culture". He lived and was deeply involved in the "platforms" which permeated this society. What emerged was a relationship nurtured in a situation of what Beittel called a "meaningful generality." It speaks of understanding the idiosyncratic way such relationships are formed and develop. In terms of his relationship with David, Beittel wrote:

That I have influence, however, I will not deny. But it is an oblique one. It is the influence of my participation in the community, in the environment, atmosphere, or climate arising from our two families, our closeness to nature, and our common pursuits. As such, one does not "plan" his influence. It happens, like the existential "meeting" in Martin Buber's philosophy (p. 24).

As a teacher, artist, and graduate student working with beginning teachers I look to these authors as a way to better understand my own situation as teacher-artist-student and as a possible guide in directing beginning teachers to more fully understand their newly emerging roles. I found that observation and reflection were essential to a clearer understanding of this relationship. A need to be self-reflective was apparent and came to light in a journaling experience which occurred the summer after I began working with student teachers. I wrote:

Each Tuesday night during the past year I met with a small group of students who had begun their student teaching experience. These regular meetings served as a forum for students to discuss important events, concerns, problems and new information they wanted to address.

Many nights, after each seminar, I reflected upon my own student teaching experience. The initial uncertainty and fright as I walked into that art room for the first time are still with me today. The environment seemed foreign and I felt a bit like an intruder.

As a student teacher, $i$ felt the awkwardness that the title implied. I was a student and a teacher at the same time. My perceptions of myself and the perceptions students, my cooperating teacher and other teachers had of me, vacillated 
as my role changed and emerged each day I spent in school. As I grew and understood more about myself as a teacher my relationship with the students became more authentic. The importance and specialness of this position became evident to me.

With this grounding, I asked beginning teachers to keep a Journal of their experiences that became, as Grumet (1975) described, "stories that I tell about my experiences" (p. 75). This approach, grounded in the existential and phenomenological validity of inquiry, recognizes the existence of the world without-as Beittel pointed out-explaining its facticity and accepts our experience of it without first establishing its causality. In these journals then, to remember an event-to refiect--is to experience it again. Meaning becomes a way of focusing one's gaze at an item of one's own experience.

The process of inquiry, to look back to our past experience as a way to provide a clearer understanding of the present and a guide for the future, was a process I suggested students undertake. It encouraged a clearer understanding of themselves in their new role. Connelly and Clandinin (1988) regarded this as the "personal". For them the personal becomes something in the past, something in the present, something in the future. We need to know the parts, but it is in the whole that we find most meaning.

As in my own case, the first apprehension expressed by many beginning teachers was their introduction into this new situation and their forthcoming role. Burkhart and Neil (1968) looked at this in terms of teacherlearning Identity problems (p. 31). Like many others, they stressed the importance of reflection as a method to get a clearer understanding of this new identity. Its importance to the student teacher comes out in the following journal entry:

I spent my first day observing. Most of the students talked to each other as they worked. Their conversations seem to be about relationships, their activities in school, drugs, drinking, world politics, school politics, family politics and clothes. This high school is really not much different than my own high school twenty years ago. The big difference I noticed that day was not with the students or school but with my own thoughts and feelings in coming back to this environment, coming to terms with my new role, asking myself when did I grow up and become an adult and being somewhat amused at thinking of myself as a teacher in high school.

The student teacher, upon first walking through the school's doors, enters more than a building, as a complex, active bearer of habits, values, and beliefs-as a unique person-he or she enters a now community in which roles, relationships, ways of behaving, and understandings--for better or worse-are 
already established and give that particular school its unique quality. It is in this setting that the student teacher begins to establish his or her identity.

Perhaps more than anything else it is the students, in their vast numbers and with a multitude of untold stories, who help student teachers understand their role and the milieu of the school and classroom. After eight days in the art room. Cindy found this process unfolding:

Since day one, no... period one, I felt myself establishing bonds with two of the sixth grade girls. Shawn-a cute little girl who was working at the computer, and Katie--her friend, who immediately came up to me and asked for my life story. Katie must have sensed that I was nervous, for before she left class she assured me that I would do fine as a student teacher.

A few days later, towards the end of the trimester, Katie gave me a wooden heart she had painted. As I watched her leave, I heard her tell her friend that I was her "bud".

Working with 6th, 7th and 8th grade classes, 1 have found similar, responsive reactions. The kids are terribly curious. Who am I? How old am I? Am I married? Do I have children? What kind of music do I like?" In reaction to their inquiries, I turn around and ask them about themselves. What do you like to do? Where do you like to go? What do you like to draw? What other things do you like to make? Can I see your artwork? May I look through your art folder?" They love to be asked things. I think they can sense my interest in them.

A teacher must be seen as more than someone who disseminates a fixed amount of knowledge five times a day for 180 days. Already, on her first day, as she began to make meaning in her situation, Cindy found the importance of learning from her students. Her use of questions-some of the same questions students "used" on her-was an effective way to begin her inquiry into the lives and stories of the young people which would help her to understand her role in this new world. The journal then became what Beittel described as a "multiple-consciousness narrative."

At a time when various strategies are being adopted to minimize teacher influence-it seems even more important to adopt and reaffirm the humanistic traditions found in teaching art. Programmed learning textbooks, standardized curricula, computer assisted instruction, and highly prescriptive textbooks detailing what the teacher should say and even do at particular times and giving answers to questions teachers might pose to students have nothing to do with the idea of relationship discussed thus far.

Working Papers in Art Education 1992 
Whether or not "educational specialists" want to admit it-these materials often do not serve the purposes of the students they were created for. Strict compliance of these guidelines and procedures often seems to pit teacher against student. Instead of encouraging learning, these programs often exude a sense of betayal. The individuality of the students, their situations and histories are given no importance. It is no wonder that students view their situation with resentment: as captive, waiting for the bell to ning.

In Sometimes a Shining Moment: The Foxfire Experience, Eliot Wigginton reached the point where he could no longer operate in this manner (following the established text and curriculum offered nothing but frustration, distrust and discouragement). The following excerpt from his book illustrated the importance of centering curriculum in the lives of the students one encounters:

On one of the bleakest fall days of 1966, I walked into my firstperiod class, sat down on top of my desk and crossed my legs, and said, very slowly and very quietly, "Look, this isn't working. you know it isn't and I know it isn't. Now what are we going to do together to make it through the rest of the year?"

The class was silent. For long minutes we simply stared at each other. And then slowly, quietly, the talk came. Nothing of real consequence got resolved that day in terms of specific classroom activities that they might enjoy more than what I had imposed on them ... But at least we began the dialogue, and we began to look at each other in a different light.

The process of examining ourselves, English and what it's for, school and what it's for, and sampling new activities went on all year. In fact, ten years later at Rabun Gap, I and new students were still at it-still tearing things apart and putting them together in different ways. Still expenimenting. Still talking. Still testing. And I still do it with my students today at Rabun County's new consolidated public high school, where I now teach. And being a slow leamer, I still haven't got it right. But l'm getting there (Wigginton, 1985, p. 32).

Through the concerted efforts of many students working to set up an intaglio printmaking area at a local school, Lisa, a student teacher, found the importance of student insight and experience. She wrote:

For the past three weeks I have been working with the art teacher and students at City High to set up a printmaking area. We uncovered a dusty press with handles missing and rust covering the rollers and bed and refurbished it. Every inch of the press was scoured with steel wool and rubbed 
with oil. We made many trips to Lenoch and Cilek and some of the best solutions to problems have come from students. My favorite idea was for covering the handles to the press. To begin with, we replaced missing handles with threaded steel rods that screwed into the spokes. We found the threaded rods at the hardware store but they left a greasy film on your hands after you touched them and they cut into your hands. Lyla, a senior at City High, thought of covering the handles with half-inch clear plastic tubing. It worked great and gives the press a high tech look.

The art teacher forms her curriculum by looking for what is missing and trying to add to those elements. In considering my situation at City High, I hope I can act as one of those missing links with the experience I bring as a printmaker--to become a living aspect of the curriculum.

Art, generally considered a richly individual activity, becomes routine and empty when it is treated as a prescribed set of standards imposed on students without any regard for their individuality. Art therapist Edith Kramer (Zurmuehlen, 1974) suggested that the problem is emptiness. "All teaching methods can be corrupted by mechanical appllcation" (p. 13).

Margaret Naumberg (Zurmuehlen, 1974) addressed the relationship between art and the creative process in the teaching still offered in many schools today. "When art teaching is dealt with as a routine process, it discourages efforts at spontaneous and creative expression and forces pupils into a degree of stereotyped reproduction of known models that encourages regression and evasion of creative effort" (p. 13).

While Grumet (1975) contended that:

The analysis of educational experlence ... is not an attempt to talk about education but to intensify the student's experlence of $\mathrm{t}$, to broaden his use of it by making it a lived meaning, a form ... of "ontological disclosure." When ... one asks students the question, "What does this mean to you?" the process of translation and interpretation is initiated and is then extended through the dialogue the student has with himself (p. 118).

In art education, the individuality of each student must be respected and maintained; attention should be directed to the process of living out the stories we tell ourselves in order to make meaning of our experience. Teachers of art must be sensitive and reflective. They must accept, respect and nurture the uniqueness and individuality of their students. The importance of truly "knowing" our students is aptly described by Zurmuehlen in the following passage:

Working Papers in Art Education 1992 
I propose that authentic learning is more likely to occur when teachers have the sensibility of artists, when they abandon impersonal curricula and methods that supply only borrowed contexts and seek occasions in which they can reasonably hope their students may construct personal contexts. Like Robert Imin, teachers can begin with what is "on their way" for students, individually and collectively. Through actively encouraging reflection, contexts are acknowledged and everydayness is transformed in living interpretations by drawing and painting, shaping and building, seeing and touching, and wrlting and telling. Such learners are not ignored or damaged receptacles for specimens assembled by strangers. They are individuals, sovereign, on their ways, constructing meaning in their lives (1986, p. 36).

\section{References}

Beittel, K R. (1963, September). David's stonewares. School Arts, pp. 2327.

Beittel, K R. (1973). Alternatives for art education research: Inquiry in to the making of art. Dubuque, IA: Wm. C. Brown.

Buber, M. (1965). Between man and man. New York: Macmillan.

Buber, M. (1970). I and thou. New York: Charles Scribner's Sons.

Burkhart, R., \& Neil, H. M. (1968). Identlty and teacher learning. Scranton, PA: International Textbook Co.

Connelly, E. M., \& Clandinin, D. J. (1988). Teachers as curriculum planners. Columbia Unlversity: Teachers College Press.

Grumet, M. (1975). Existential and phenomenological foundations. In W. Pinar (Ed.), Toward a poor curriculum. Dubuque, IA: Wm. C. Brown.

Grumet, M. (1975). Toward a poor curriculum. In W. Pinar (Ed.), Toward a poor curriculum. Dubuque, IA: Wm. C. Brown.

Schutz, A. (1970). On phenomenology and social relations. Chicago: University of Chicego Press.

Weschler, L. (1982). Seeing is forgetting the name of the thing one sees. Berkeley: University of California Press.

Wigginton, E. (1985). Sometimes a shining moment: The Foxfire experience. Garden City, New York: Anchor Press/Doubleday. 
Zurmuehlen, M. (1974, March). Meaningful children's art. School and community, pp. 12-13, 33.

Zurmuehlen, M. (1986, November). Interpretation as transformation of experiences. Art Education, pp. 33-36. 